\title{
Pengembangan Modul Pembelajaran Berbasis Masalah untuk Membantu Meningkatkan Kemampuan Penalaran Siswa SMK pada Materi Fungsi, Persamaan Fungsi Linier dan Fungsi Kuadrat
}

\author{
Rachmadania Akbarita ${ }^{(1)}$ Risang Narendra ${ }^{(2)}$ \\ ${ }^{1,2}$ Program Studi Matematika \\ ${ }^{1,2}$ Universitas Nahdlatul Ulama Blitar \\ 1dania.barita@gmail.com, \\ ${ }^{2}$ risangnarendra@gmail.com
}

\begin{tabular}{l} 
Tersedia Online di \\
http://www.jurnal.unublitar.ac.id/ \\
index.php/briliant \\
\hline Sejarah Artikel \\
\hline Diterima pada 16 November 2018 \\
Disetuji pada 25 Januari 2019 \\
Dipublikasikan pada 20 Februari \\
2019 Hal. 1-4 \\
\hline
\end{tabular}

\begin{tabular}{l}
\hline Kata Kunci: \\
\hline Modul, SMK, Fungsi Linier, \\
Pembelajaran Berbasis Masalah \\
\hline \\
\hline DOI: \\
\hline http://dx.doi.org/10.28926/briliant \\
.v3i3.255 \\
\hline
\end{tabular}

\begin{abstract}
Abstrak: Pembelajaran matematika bagi siswa perlu memperhatikan pengembangan kemampuan penyelesaian masalah (problem solving). Kemampuan penyelesaian masalah berdasarkan Pola terdapat empat tahap, yaitu understanding the problem, devising a plan, carrying out the plan, looking back. Salah satu cara untuk meningkatan penalaran siswa adalah dengan modul pembelajaran berbasis masalah.Sehingga tujuan dari penelitian ini adalah untuk untuk menghasilkan modul pembelajaran berbasis masalah yang dapat meningkatkan kemampuan penalaran peserta didik kelas XI Sekolah Menengah Kejuruan (SMK) pada materi fungsi, persamaan fungsi linier dan fungsi kuadrat.
\end{abstract}

\section{PENDAHULUAN}

Salah satu keterampilan matematis yang harus dikuasai peserta didik adalah kemampuan penalaran. Keraf (Ario, 2016) menyatakan bahwa penalaran adalah proses berfikir yang berusaha menghubungkan fakta-fakta yang diketahui menuju kepada suatu kesimpulan. Kesimpulan yang bersifat umum bias ditarik dari kasus-kasus yang bersifat individual, akan tetapi dapat juga sebaliknya dari hal yang bersifat individual menjadi bersifat umum. Baroody (1993) mengatakan bahwa penalaran adalah alat yang penting untuk matematika dan kehidupan sehari-hari. Kemampuan penalaran matematis menjadi semakin penting untuk peserta didik yang memilih Sekolah Menengah Kejuruan (SMK).

Sekolah Menengah Kejuruan (SMK) merupakan lembaga pendidikan yang berpotensi untuk mempersiapkan SDM yang dapat terserap oleh dunia kerja, karena materi teori dan praktik yang bersifat aplikatif telah diberikan sejak pertama masuk SMK, dengan harapan lulusan SMK memiliki kompetensi sesuai dengan kebutuhan dunia kerja. Materi fungsi, persamaan fungsi linier dan fungsi kuadrat merupakan salah satu materi dalam mata pelajaran matematika yang diberikan untuk peserta didik kelas XI Sekolah Menengah Kejuruan (SMK). 
Salah satu cara untuk meningkatkan kemampuan belajar peserta didik diperlukan suatu pembelajaran yang efektif, yaitu dengan menggunakan pembelajaran berbasis masalah (Problem Based Learning). Pembelajaran berbasis masalah (Problem Based Learning) adalah suatu model pembelajaran yang melibatkan peserta didik aktif untuk memecahkan masalah melalui tahap-tahap metode ilmiah. Dalam pembelajaran berbasis masalah (Problem Based Learning) kemampuan berfikir peserta didik betul-betul dioptimalisasikan melalui kerja kelompok atau tim yang sistematis, sehingga peserta didik dapat memberdayakan, mengasah, menguji, dan mengembangkan kemampuan berfikirnya secara berkesinambungan.

Sumber belajar yang dapat digunakan berupa modul. Modul merupakan alat atau sarana pembelajaran yang berisi materi, metode, batasan-batasan, dan cara mengevaluasi yang dirancang secara sistematis dan menarik untuk mencapai kompetensi yang diharapkan (Suryana). Modul adalah bahan ajar yang disusun secara sistematis dan menarik yangmencakup isi materi, metode, dan evaluasi yang dapat digunakan secara mandiri.

Hasil observasi menunjukkan bahwa kebanyakan guru belum mengembangkan kemampuan penalaran matematika kepada peserta didik dalam pembelajaran di sekolah, terutama pada materi fungsi, persamaan fungsi linier dan fungsi kuadrat. Guru hanya memberikan informasi kepada peserta didik dan memberikan contoh soal beserta penyelesaiannya, selanjutnya peserta didik dilatih untuk menyelesaikan banyak soal tanpa ada pemahaman yang mendalam. Akibatnya, kemampuan penalaran matematis peserta didik tidak berkembang sebagaimana semestinya. Menurut hasil wawacara terhadap salah satu guru matematika, dapat diketahui bahwa salah satu materi yang sulit dalam kurangnya penalaran matematis tersebut, berakibat hasil ulangan harian peserta didik pada materi fungsi, persamaan fungsi linier dan fungsi kuadrat yang dibawah Kriteria Ketuntasan Minimal (KKM). Lebih lanjut, guru berpendapat bahwa peserta didik hanya sebatas menghafal, tanpa didasari pemahaman yang lebih terhadap materi tersebut. Salah satu alasan yang disampaikan adalah guru merasa kesulitan menyampaikan materi kepada peserta didik.

Dengan uraian tersebut, maka penulis akan mengembangkan modul pembelajaran berbasis masalah yang dapat meningkatkan penalaran matematis pada materi fungsi, persamaan fungsi linier dan fungsi kuadrat kelas XI Sekolah Menengah Kejuruan (SMK) Kabupaten Blitar.

\section{METODE}

Metode yang dilakukanyaitupenelitiandan pengembangan (Research and Development) dengan mengacu pada model pengembangan Thiagarajan, yaitu (1) Define, (2) Design, (3) Develop, dan (4) Disseminate. Subjek pada penelitian ini adalah peserta didik kelas X SMK Al Khusna Ponggok Kabupaten Blitar. Sedangkan luaran dari penelitian ini adalah modul berbasis masalah dengan materi fungsi, persamaan fungsi linier dan fungsi kuadrat.

\section{HASIL}

Uji ahli modul menunjukkan hasil valid dan telah diperbaiki menurut saran dan komentar ahli. Uji coba modul bertujuan untuk mengetahui tingkat pemahaman siswa terhadap materi sajian pada modul. Dari hasil angket respon 
peserta didik setelah mengikuti kegiatan pembelajaran, didapatkan bahwa sebesar 90,10\% setuju dengan modul yg telah dikembangkan.

\section{PEMBAHASAN}

Hasil akhir dari pengembangan ini adalah Modul Pembelajaran Berbasis Masalah Untuk Membantu Meningkatkan Kemampuan Penalaran Siswa SMK Pada Materi Fungsi, Persamaan Fungsi Linier dan Fungsi Kuadrat yang telah melewati tahap uji ahli dan memperoleh hasil valid. Sebelumnya modul telah diujicobakan pada 9 peserta didik. Dari hasil uji coba didapatkan bahwa peserta didik dapat menerima pembelajaran dengan alat bantu berupa modul. Hal ini dapat dilihat dari tes yang telah dilakukan. Dari 9 peserta didik, terdapat 2 yang nilainya dibawah standar.

\section{KESIMPULAN}

Berdasarkan hasil penelitian dan pembahasan yang sudah diuraikan pada bab sebelumnya, dapat disimpulkan bahwa modul pembelajaran berbasis masalah dapat membantu meningkatkan kemampuan penalaran siswa smk pada materi fungsi, persamaan fungsi linier dan fungsi kuadrat.

\section{SARAN}

Saran yang dapat diberikan untuk pengembangan produk lebih lanjut adalah dikembangkan lebih lanjut, sebaiknya dikembangkan untuk materi-materi lain dan tetap memperhaikan kesesuaiannya atau perbaikan dari kelemahankelemahan yang muncul dalam perangkat pembelajaran ini. Dalam penelitian ini, implementasi dalam arti luas tidak dilakukan karena penelitian tidak bertujuan untuk membuat generalisasi, namun demikian untuk pengembangan lebih lanjut desain ini dapat digunakan dalam konteks yang lebih besar.

\section{DAFTAR RUJUKAN}

Agustiani, Iguk. 2013. Pengembangan Modul Pembelajaran Berbasis Masalah yang Dapat Meningkatkan Penalaran Siswa pada Materi Program Linier. Tesis tidak diterbitkan. Malang: PPs UM.

Ario, Marfi. 2016. Analisis Kemampuan Penalaran Matematis Siswa Smk Setelah Mengikuti Pembelajaran Berbasis Masalah. Jurnal Ilmiah Edu Research Vol. 5 No. 2.

Barrody, A, J. (1993). Problem Solving, Reasoning, and Communicating, (K-8): Helping Children Think Mathematically. New York: Merill as imprint of Macmillan Publishing Company.

Depdiknas. 2008. KamusBesar Bahasa Indonesia Pusat Bahasa Edisi IV. PT GramediaPustakaUtama: Jakarta

NCTM. 2000. Principles and Standarts for School Mathematics. NCTMInc : United States Of America.

Rusman, 2012. Model-Model Pembelajaran. Bandung: RajagrafindoPersada.

Shahida, Baig, \&Halai, Anjum. 2006. Learning Mathematics Rules with Reasoning. Eurasia Journal of Mathematics, Science and Technology Education.

Suryana. 2013. Keunggulan dan Kelemahan Pembelajaran Berbasis Masalah, (Online), (http://www.referensimakalah.com/2012/08/karakteristik- 
pembelajaran-berbasis-masalah-Problem-Based-Learning-PBL.html), diakses 2 Mei 2016.

Thiagarajan, S., Semmel, D.S., danSemmel, M.I. 1974. Intructional Development for Training Teachers of Exceptional Children. Minnesota: University of Minnesota. 